Joanna Machlańska (Kraków)

\title{
Powtórzenie (recydywa) przestępstw w rosyjskim prawie karnym XIX w.
}

\section{WPROWADZENIE}

Recydywa to w rozumieniu potocznym ponowne popełnienie przestępstwa bez względu na to, czy nowy czyn wypełnia znamiona tego samego, podobnego lub innego typu czynu zabronionego oraz niezależnie od czasu, jaki upłynął od dokonania poprzedniego czynu. W niniejszym opracowaniu zostanie zaprezentowana instytucja powtórzenia przestępstwa w rosyjskim ustawodawstwie XIX w. (legislator nie posługiwał się określeniem „recydywa”) i analiza poszczególnych uregulowań tego okresu, tj.: Zwodu praw, Kodeksu kar głównych i poprawczych oraz ustawy o karach wymierzanych przez sędziów pokoju.

\section{ZWÓD PRAW IMPERIUM ROSYJSKIEGO Z 1832 R.}

Zwód praw ma szczególne znaczenie w rosyjskim ustawodawstwie. Twierdzi się wręcz, że z chwilą jego wydania „naród dowiedział się, co to prawo, gdzie jego początek, a gdzie jego koniec"1, gdyż akt ten uporządkował dotychczasowe chaotyczne i bardzo liczne postanowienia oraz ukazy. Ze względu na przedmiot niniejszego opracowania omówione zostaną zapisy zawarte w tomie XV z 1832 r. - Zwód praw karnych, który jako pierwszy w historii prawodawstwa oddzielił od siebie normy prawa karnego materialnego i procesowego, wyodrębnił

${ }^{1}$ М.В. Шимановский, О значении свода законов Российской империи для науки и жизни, Odessa 1928, s. 3. 
część ogólną i szczególną oraz usystematyzował poszczególne instytucje prawne, a systematyka ta z pewnymi wyjątkami obowiązuje po czasy współczesne ${ }^{2}$.

Omawiając Zwód praw pod kątem problematyki powrotu do przestępstwa, wskazać należy, że jeśli sprawca popełnił przestępstwo już po ukaraniu go za przestępstwo poprzednie, wówczas było to nie ze skupienie się przestępstw (zbiegiem przestępstw), z ich powtórzenie. Artykuł 124 Zwodu praw (art. $135 \mathrm{w}$ brzmieniu od 1842 r.) stanowił, że „powtórzenie tego samego przestępstwa pomnaża winę przestępcy. Za powtórzenie przestępstw uważa się to, kiedy przestępca, będąc ukaranym za przestępstwo, uczynił to samo drugi lub trzeci raz"’3.

Powtórzenie przestępstwa zostało uznane za okoliczność zwiększającą winę przestępcy oraz prowadzącą do zaostrzenia kary bądź wymierzenia kary bardziej surowej ${ }^{4}$. W literaturze wskazuje się, że była to pierwsza próba zdefiniowana przez rosyjskiego ustawodawcę tego terminu ${ }^{5}$. Nie była ona jednak do końca udana, gdyż literalna wykładnia ww. przepisu musiała prowadzić do uznania, że popełnienie kilku przestępstw realizujących znamiona różnych typów czynów zabronionych nie stanowi powtórzenia przestępstw, o których mowa w art. 124 Zwodu praw, co uniemożliwiało zaostrzenie kary w takich przypadkach. Dlatego też NikołajTagancew ${ }^{6}$ stwierdził, że art. 124 mówił o „powtórzeniu specjalnym”,

2 Г.С. Досаева, Множественность преступлений в уголовном праве России: историкоправовой анализ: Монография, Rostów nad Donem 2011, s. 27.

${ }^{3}$ Г.С. Досаева, Множественность преступлений..., s. 28. Treść tego przepisu nie została oparta na oryginalnej treści Zwodu praw ze względu na niemożność dotarcia do niej, lecz na cytowaniu tego przepisu w literaturze - zob. Э.Г. Шкредова, Множественность преступлений (исторический аспект), Moskwa 2011, s. 10.

${ }^{4}$ О.И. Горегляд, Опыт начертания российского уголовного права. Часть I. О преступлениях и наказаниях вообще, Sankt Petersburg 1815, s. 86; Г.И. Солнцев, Российское уголовное право, Kazań 1820 [w:] red. Г.С. Фельдштейн, Jarosław 1907, s. 63.

5 Э.Г. Шкредова, Уголовное законодательство и доктрина начала XIX в. о множественности преступлений, [w:] red. И.М. Машаров, Актуальные проблемы юридической науки и правоприменительной практики. Сборник научных трудов (по материалам 4 международной научно-практической конференщии, состоявшейся 15 октября 2005 г.): в 3-х частях, Kirow 2005, t. 3, s. 298.

${ }^{6}$ Prace Nikołaja S. Tagancewa, a w szczególności: O повторении преступлений. Исследование, Sankt Petersburg 1867; Курс русского уголовного права: Учение о преступлении. Часть общая, Sankt Petersburg 1880; Русское уголовное право. Часть общая, Tuła 2001, t. 2, co prawda odnoszą się do dawno już nieaktualnego stanu prawnego, jednak ze względu na dogłębne omówienie dogmatyczno- i teoretycznoprawne problemy wielości przestępstw i jej konsekwencji na płaszczyźnie wymiaru kary stanowią najcenniejsze źródło wiedzy. Swoje badania autor prowadził ponadto w perspektywie prawnoporównawczej, odnosząc się m.in. do prawa francuskiego, belgijskiego i niemieckiego, a jego ww. monografia dotycząca powtarzalności przestępstw była jedynym tego typu opracowaniem o wielości przestępstw w latach 1815-1917 (i która nota bene stanowiła pracę magisterską Nikołaja S. Tagancewa), w związku z czym prace właśnie tego autora w części historycznej niniejszego artykułu będą najczęściej przywoływane. 
którego warunki były rozumiane wąsko jako wymóg takiej samej kwalifikacji prawnej. Natomiast ponowne wypełnienie znamion jakiegokolwiek typu czynu zabronionego po wcześniejszym ukaraniu sprawcy zakwalifikował jako „powtórzenie ogólne" ", co nie oznaczało, że powtórzenie to nie miało wpływu ma wymiar kary, gdyż w takich przypadkach nie było możliwości złagodzenia kary, a to ze względu na treść art. 131 Zwodu, stanowiącego, że sąd, łagodząc karę, bierze pod uwagę zachowanie sprawcy, w szczególności, czy był już karany grzywną8.

Jako jedyny przedstawiciel piśmiennictwa omawianego okresu, Nikołaj Tagancew wyjaśnił różnicę pomiędzy skupieniem się przestępstw a ich powtórzeniem, wskazując, że sformułowanie „będąc ukaranym” („будучи наказан”) użyte w art. 124 Zwodu trzeba odróżnić od pojęcia „skazany” („осужdен”). Jako „ukaranie” autor ten rozumiał odbycie całości kary, powołując się na literalne brzmienie przepisu oraz na samą sposobność zaostrzenia kary w przypadku powtórnego popełnienia przestępstw przez tego samego sprawcę. Jeśli bowiem pomimo odbycia kary przez skazanego ponownie popełnił on przestępstwo, to oznacza, że poprzednia kara nie była wystarczająco wysoka, zatem kolejna powinna być bardziej surowa ${ }^{9}$. Z tego wynika, że sam fakt skazania za poprzedni czyn nie świadczył o niemożliwości zastosowania instytucji skupienia się przestępstw - jeśli sprawca popełnił nowe przestępstwo zanim odbył karę w całości, sąd powinien zastosować normę o skupieniu się przestępstw, a nie o ich powtórzeniu. Takie podejście z jednej strony prowadzi do wniosku, że konstrukcja skupienia się przestępstw określona w Zwodzie praw nie odpowiadała w tej części współczesnemu rozumieniu zbiegu przestępstw, a z drugiej strony - powtórzenie przestępstw ze względu na wymóg odbycia kary można porównać do dzisiejszej recydywy.

Wydawałoby się, że konieczność odbycia kary za poprzednie przestępstwo jako warunek konstytutywny powtórzenia przestępstw oznaczał, że instytucji tej nie można było zastosować w przypadku, gdy doszło do przedawnienia wykonania kary za pierwszy z czynów lub ułaskawienia. Jednak wówczas rosyjskie ustawodawstwo nie przewidywało przedawnienia wykonania kary, a wyłącznie przedawnienie ścigania przestępstw. W odniesieniu zaś do ułaskawienia trzeba wskazać art. 136 Zwodu praw (dodany nowelizacją z 1842 r.), który stanowił, że nie usuwało ono możliwości zastosowania powtórzenia, a wręcz przeciwnie -

\footnotetext{
${ }^{7}$ Natomiast Stanisław Budziński rozróżniał pojęcia powtórzenia właściwego (popełnienie tego samego przestępstwa) oraz powtórzenie niewłaściwe (popełnienie przestępstwa innego rodzaju) zob. S. Budziński, O powtarzaniu przestępstw wedle Kodeksu karnego obowiązującego, Warszawa 1875, s. 6.

${ }^{8}$ Н.С. Таганцев, О повторении преступлений..., s. 266-268.

9 Ibidem, s. 61, 267.
} 
fakt, że pomimo ułaskawienia sprawca popełnił kolejne przestępstwo nie powodował, że ustawodawca traktował sprawcę łagodniej ${ }^{10}$.

W przypadku powtórzenia przestępstw Zwód praw nie zawierał uniwersalnych reguł wymiaru kary, które byłyby ujęte w części ogólnej, w związku z czym wymiar ten zależał od oceny sędziego, chyba że przepisy części szczególnej Zwodu określały wymiar kary. W takich przypadkach co do zasady karę podwajano lub dodawano do poprzedniej kary nową lub wymierzano karę bardziej surową. Niekiedy wymiar kary za powtórzenie przestępstw był bardzo restrykcyjny, na przykład za pierwszy potajemny przewóz towarów wymierzano lekką karę cielesną, natomiast za trzecim razem - zsyłano na katorgę (art. 508) ${ }^{11}$.

Zwód praw nie regulował sytuacji powtórzenia przestępstw w różnych formach - zjawiskowych lub stadialnych - a jak już wcześniej wspomniano - istniał jedynie wymóg tożsamości kwalifikacji prawnej. W tym kontekście N.S. Tagancew wspominał, że inna forma stadialna lub rola w popełnieniu przestępstwa (sprawca bezpośredni, podżegacz, itd.) „nie zmienia charakteru popełnianego czynu, a tylko stopień wymiaru karu"12, w związku z czym w takich przypadkach kolejne przestępstwo można zakwalifikować w oparciu o instytucję powtórzenia.

Przytoczone uregulowanie pozwala stwierdzić, że zastosowanie tej instytucji było możliwe niezależnie od tego, czy popełnione czyny tego samego sprawcy były przedmiotem jednego lub kilku postępowań w tym samym czy różnych sądach. Istotne było, by w takich sytuacjach zapadł jeden ogólny wyrok ${ }^{13}$.

\section{KODEKS KAR GŁÓWNYCH I POPRAWCZYCH}

Celem wprowadzenia Kodeksu kar głównych i poprawczych (dalej: k.k.g.p.), który wszedł w życie już po 10 latach istnienia w porządku prawnym Zwodu praw (1845 r.), była m.in. eliminacja dotychczasowych niedookreślonych terminów oraz dokonanie zmian, które z uwagi na upływ czasu uznano za konieczne. Ustawa ta jest uważana przez historyków za pierwszy rosyjski kodeks karny ${ }^{14}$, a na podkreślenie zasługuje fakt, że głównym autorem rosyjskiej i polskiej wersji tego aktu prawnego był Polak, Romuald Hube, przedstawiciel klasycznej szkoły

${ }^{10}$ Ibidem, s. 267-268.

11 Ibidem, s. 270.

12 Ibidem, s. 269.

${ }_{13}$ Н.С. Таганцев, Русское уголовное право..., t. 2, s. 394-395.

${ }_{14}$ О.В. Андрусенко, Систематизация уголовного законодательства Российской империи (первая половина XIX века), Jekaterynburg 2000, s. 7. 
prawa karnego i zwolennik odwetowej teorii kary ${ }^{15}$. Podczas obowiązywania Kodeksu zostały opublikowane trzy główne wydania: w latach 1857, 1866 i 1885 , jednak nowelizacji było znacznie więcej. System kar był niezwykle represyjny, oparty na teorii odstraszania, a jednocześnie bardzo rozbudowany, przewidujący dwa podstawowe rodzaje kar: główne ${ }^{16}$ i poprawcze ${ }^{17}$, które następnie dzieliły się na stopnie.

15 J. Bardach, B. Leśnodorski, M. Pietrzak, Historia państwa i prawa polskiego, Warszawa 1987, s. 398-399.

${ }^{16}$ Art. 18. Na podstawie art. 3 niniejszego Kodeksu wszystkie kary określone przez prawo za przestępstwa i wykroczenia należą do dwóch głównych kategorii: kar głównych i kar poprawczych. Każda z tych głównych kategorii dzieli się na kilka rodzajów i stopni, jak zostało dokładnie oznaczone w artykułach: 19, 21, 22, 23, 34, 35, 36, 37, 38, 39, 40, 41, 42, 43 i 44 niniejszego Kodeksu.

Art. 19. Określone przez ustawę kary główne są następujące:

I. Pozbawienie wszystkich praw stanu i kara śmierci.

II. Pozbawienie wszystkich praw stanu i zesłanie na ciężkie roboty; dla osób niewyłączonych od kar cielesnych publiczna kara chłosty od trzydziestu do stu razów rózgą przez kata z piętnowaniem i także zesłanie na ciężkie roboty z utratą wszystkich praw stanu.

III. Pozbawienie wszystkim praw stanu i zesłanie na osiedlenie w Syberii, dla osób niewyłączonych od kar cielesnych publiczna kara chłosty od dziesięciu do trzydziestu razów rózgą przez kara, lecz bez piętnowania i także zesłanie na osiedlenie w Syberii z utratą wszystkich praw stanu.

IV. Pozbawienie wszystkich praw stanu i zesłanie na osiedlenie za Kaukaz.

${ }_{17}$ Art. 34. Kary poprawcze określone przez ustawę są następujące:

1. Utrata wszystkich szczególnych praw i przywilejów, tak osobiście, jak i otrzymanych ze względu na stan skazanego i zesłanie na mieszkanie do bardziej lub mniej odległych miejscy Syberii z czasowym osadzeniem w określonym miejscu jego zamieszkania lub bez takiego osadzenia; dla osób niewyłączonych od kar cielesnych kara od pięćdziesięciu do stu razów rózgami przez służbę policyjną i oddanie na czas określony do rót aresztanckich resortu cywilnego z utratą wszystkich szczególnych praw i przywilejów osobiście lub ze względu na stan lub stopień otrzymanych.

II. Zesłanie na mieszkanie do innej niż syberyjska mniej lub bardziej odległej guberni z utratą wszystkich szczególnych praw i przywilejów, tak osobiście, jak i ze względu na stan skazanego przez niego otrzymanych z czasowym osadzeniem w określonym miejscu jego zamieszkania lub bez takiego osadzenia; dla osób niewyłączonych od kar cielesnych osadzenie w domu roboczym również z utratą wszystkich szczególnych praw i przywilejów osobiście lub ze względu na stan lub stopień otrzymanych.

III. Czasowe osadzenie w twierdzy z utratą niektórych tylko szczególnych praw i przywilejów osobiście lub ze względu na stan lub stopień otrzymanych lub bez ich utraty, biorąc pod uwagę rodzaj przestępstwo i miarę winy.

IV. Czasowe zamknięcie w domu poprawy z pozbawieniem niektórych tylko szczególnych praw i przywilejów osobiście lub ze względu na stan lub stopień otrzymanych lub bez ich utraty $\mathrm{z}$ uwagi na rodzaj przestępstwo i miarę winy.

V. Czasowe osadzenie w wieży (areszt publiczny).

VI. Areszt na czas krótki.

VII. Nagany w obecności sądu; wypomnienia i przestrogi udzielane przez władze sądowe lub rządowe; kary pieniężne. 
WYDANIE Z 1845 R.

Konstrukcja powtórzenia przestępstw w Kodeksie kar głównych i poprawczych została uregulowana następująco: „do rzędu okoliczności zwiększających winę i karę przynależy i powtórzenie tegoż samego przestępstwa lub dokonanie innego po postępowaniu sądowym i ukaraniu za pierwsze, i dokonanie nowego przestępstwa, kiedy sprawca za uprzednie, nie mniej ważne został ułaskawiony wskutek ogólnego ułaskawiającego manifestu lub szczególnego Monarszego ułaskawienia" (art. 137) ${ }^{18}$. Ponadto, w przeciwieństwie do poprzedniej ustawy, Kodeks wprowadził generalną zasadę wymiaru kary za powtórzenie przestępstw, stanowiąc, że „w wypadkach, kiedy prawo nie wyznacza wyraźnie kary za powtórzenie tegoż samego przestępstwa lub za dokonanie innego trzeci lub czwarty raz itd., sąd zawsze wymierza najwyższą miarę kary za to przestępstwo, lub za powtórzenie go, lub za dokonanie trzeci raz" (art. 138 k.k.g.p.).

Nie budzi zastrzeżeń, że w Kodeksie kar głównych i poprawczych odrzucono zasadę, że ponowne popełnienie wyłącznie takiego samego przestępstwa stanowi powtórzenie, czyli okoliczność zwiększającą stopień winy i kary. Przytoczone przepisy Kodeksu wprowadziły dość specyficzne i niejednoznaczne uregulowanie, otwierające pole do rozmaitych interpretacji. Literalna wykładnia art. 137 k.k.g.p. zdaje się sugerować, że dokonanie po raz drugi i kolejny takiego samego przestępstwa (tzw. przestępstwa tożsamego - realizującego znamiona tego samego typu czynu zabronionego) stanowiło powtórzenie, natomiast jeśli idzie o popełnienie przestępstwa innego niż poprzednie, to tylko dokonanie go po raz trzeci i następny stanowiło powtórzenie, z czego wynika, że nie stanowiło powtórzenia popełnienie drugiego przestępstwa, które realizowało znamiona innego typu czynu zabronionego niż pierwsze. Jednakz kilka dostępnych źródeł ukazuje odmienne poglądy na tę kwestię. Po pierwsze, zgodnie z orzecznictwem Karnego Departamentu Kasacyjnego Senatu „za powtórzenie, według Kodeksu, uważa się nie tylko popełnienie tego samego, ale i jakiegokolwiek innego przestępstwa po postępowaniu sądowym i ukaraniu za pierwsze"19. Stanowisko

${ }^{18}$ Artykuł 137 k.k.g.p. został przetłumaczony na język polski w wydaniu Kodeksu z 1847 r. w następujący sposób: „Do rzędu okoliczności zwiększających winę i karę należy także powtórzenie tegoż samego przestępstwa lub popełnienie innego, po nastąpionem ukaraniu za przestępstwo poprzednio popełnione, jako też dopuszczenie się nowego, w przypadku, jeżeli winny w zarzucie popełnionego poprzednio, niemniej ważnego przestępstwa, ułaskawionym został wskutek ogólnego lub szczególnego Najwyższego postanowienia (pisownia oryginalna - Kodex kar głównych i poprawczych", Warszawa 1847, s. 81).

19 Н.С. Таганцев, Систематический свод решений кассационных департаментов Сената 1866-1871 2. с подлинным текстом решений, извлеченными из них тезисами и критическим разбором их [w:] Решения Уголовного кассаиионного департамента, разъясняюшие Уложения и Устав о наказаниях и учреждение судебных установлений, red. А. Думашевский, t. 4, Sankt Petersburg 1872, s. 154. 
to zostało zaaprobowane przez Nikołaja Tagancewa w jego monografii „O powtórzeniu przestępstw" ${ }^{20}$. W ten sam sposób kwestia ta została przedstawiona we współczesnej monografii dotyczącej historycznego rozwoju instytucji wielości przestępstw przez Glierę Dosajewą ${ }^{21}$. Następnie Nikołaj Tagancew w późniejszym podręczniku prawa karnego stanął na odmiennym stanowisku, podkreślając, że „do zwiększenia kary za powtórzenie bezwarunkowo jest niezbędne, żeby nowy czyn był albo tożsamy z poprzednim, albo jednorodny z nim"22. Po drugie, Stanisław Budziński w publikacji wydanej w języku rosyjskim stwierdził, że omawiany przepis obejmuje zarówno powtórzenie szczególne (popełnienie takiego samego przestępstwa albo przestępstwa tego samego rodzaju), jak i ogólne (popełnienie innego przestępstwa lub przestępstwa innego rodzaju) ${ }^{23}$, natomiast w polskim wydaniu wspomina wyłącznie o powtórzeniu właściwym (popełnienie tego samego przestępstwa), dodając, że ,wyrażenie »tego samego przestępstwa« nie powinno być brano w zbyt ścieśnionem znaczeniu, to jest naruszenia tego samego artykułu prawa. Przestępstwo jest to samo jak tylko podchodzi pod tę samą nazwę (oszustwa, przeniewierzenia)"24. Z kolei w innej współczesnej monografii Ewelina Szkriedowa przedstawiła pogląd, że sformułowanie „lub za dokonanie innego trzeci lub czwarty raz" odnosi się do sytuacji, w których w części szczególnej Kodeksu ustawodawca wprowadził odrębne typy statuujące powtórzenie, zatem zdaniem tej autorki art. 137 k.k.g.p. przewidywał powtórzenie specjalne (powtórna realizacja znamion tego samego typu czynu zabronionego), a art. 138 k.k.g.p. ponadto powtórzenie ogólne, jednakże podwyższenie wymiaru kary było możliwe tylko wtedy, kiedy prawodawca tak stanowił w części szczególnej usta$w^{25}$. Niestety wątpliwości te nie zostały zauważone w piśmiennictwie.

Nie uległa modyfikacji inna przesłanka powtórzenia przestępstw, tj. wymóg, by nowe przestępstwo zostało popełnione po nastąpieniu ukarania, czyli odbyciu kary w całości za poprzedni czyn ${ }^{26}$. Natomiast porównanie treści przepisów Zwodu praw oraz Kodeksu kar głównych i poprawczych statuujących zbieg (skupienie się) przestępstw $\mathrm{i}$ ich powtórzenie $\mathrm{w}$ kontekście rozszerzenia zakresu zbiegu przestępstw w omawianej ustawie również na sytuacje, w których sprawca popełnia kolejne przestępstwo przed zakończeniem postępowania sądowego za poprzednie, rodzi pytanie: jak należy traktować przypadki, w których kolejne przestępstwo jest popełnione już

${ }^{20}$ Н.С. Таганцев, O повторении преступлений..., s. 286.

${ }^{21}$ Г.С. Досаева, Множественность преступлений..., s. 38.

22 Н.С. Таганцев, Русское уголовное право..., t. 2, s. 424.

23 S. Budziński, Начала уголовного права, Warszawa 1870, s. 278.

${ }^{24}$ S. Budziński, O powtarzaniu przestępstw..., s. 23-24.

25 Э.Г. Шкредова, Множественность преступлений.., s. 10.

${ }^{26}$ S. Budziński, O powtarzaniu przestępstw..., s. 17; Н.С. Таганцев, О повторении преступлений..., s. 283. 
po tym postępowaniu sądowym, a przed ukończeniem odbywania kary za pierwsze przestępstwo (przestępstwa)? Jak wspomniano, na gruncie Zwodu praw takie okoliczności prowadziły do skazania za skupienie się przestępstw, natomiast zestawienie art. 137, 139 oraz 156 k.k.g.p. nie pozwalało na zakwalifikowanie go ani jako zbiegu, ani powtórzenia przestępstw. Luka ta w wydaniu Kodeksu z 1845 r. nie została przez ustawodawcę zapełniona, w związku z czym w opisywanych okolicznościach należało wymierzyć nową karę za kolejne przestępstwo ${ }^{27}$, która nie mogła być zaostrzana na podstawie ww. regulacji, ale jednocześnie nie podlegała łączeniu z wcześniej wymierzoną karą (karą łączną) ${ }^{28}$ i podlegała oddzielnemu wykonaniu.

Podobnie jak Zwód praw, Kodeks kar głównych i poprawczych nie ustanowił żadnego maksymalnego okresu po odbyciu kary za poprzednie przestępstwo, po upływie którego kolejne przestępstwo nie mogło być uznane za powtórzone. Nie istniało zatem przedawnienie powtarzania przestępstw ${ }^{29}$, co było rozwiązaniem niezwykle surowym.

Znamiennym dla omawianej ustawy był zwrot in fine art. 137: „kiedy sprawca za uprzednie, nie mniej ważne [przestępstwo], został ułaskawiony wskutek ogólnego ułaskawiającego manifestu lub szczególnego Monarszego ułaskawienia”. „Waga” przestępstwa odnosiła się do wymiaru kary - sformułowanie nie mniej ważne oznaczało, że kara za wcześniejsze przestępstwo nie powinna być nie tylko wymierzona w niższym wymiarze, ale również nie powinna stanowić kary niższego rodzaju. Jeśli zaś pierwsza kara była łagodniejsza, to wówczas nie mogło być mowy o powtórzeniu przestępstw w rozumieniu tego przepisu ${ }^{30}$.

Wymiar kary przewidziany w art. 139 k.k.g.p. był w istocie zbliżony do wymiaru kary za zbieg przestępstw - w obu przypadkach ustawodawca nakazywał orzeczenie kary w jej najwyższej wymiarze, w związku z czym przedstawione wyżej uwagi pozostają aktualne. Należy jednakże dodać, że w niektórych sytuacjach zasady pociągania do odpowiedzialności karnej sprawcy kilku przestępstw można było uznać za nie do końca racjonalne i adekwatne. $Z$ jednej strony sprawca wielu (więcej niż dwóch) przestępstw wchodzących w zbieg mógł być ukarany najcięższą ze wszystkich kar w jej najwyższej mierze (art. 156 k.k.g.p.), natomiast za popełnienie drugiego przestępstwa po odbyciu kary za pierwsze sprawca również mógł spodziewać się najwyższej miary kary za to przestępstwo (art. 139 k.k.g.p) ${ }^{31}$. Nie można tracić $z$ pola widzenia faktu, że zaostrzenie wymiaru kary

27 S. Budziński, O powtarzaniu przestępstw..., s. 18.

28 Н.С. Таганцев, Систематический свод..., s. 155.

29 S. Budziński, O powtarzaniu przestepstw..., s. 10; Н.С. Таганцев, Систематический свод..., s. 157; idem, Русское уголовное право..., t. 2, s. 424.

30 Idem, О повторении преступлений..., s. 288.

$31 \mathrm{Na}$ dysproporcję pomiędzy tymi dwoma przepisami wskazywał S. Budziński, twierdząc, że ,zasada ta [ujęta w art. 138 k.k.g.p. - dop. J.M.] w porównaniu z przepisem o zbiegu przestępstw 
za powtórzenie przestępstw było spowodowane powrotem do przestępstwa, a w świetle Kodeksu kar głównych i poprawczych - powrotu do przestępstwa po tym, kiedy kara za poprzednie została w całości odbyta, co - jak już wcześniej wspomniano - świadczyło o natężeniu złej woli po stronie sprawcy i niewystarczającej reakcji karnej za poprzednie przestępstwo.

Ponadto w części szczególnej Kodeks przewidywał szereg typów czynów zabronionych charakteryzujących się powtarzalnością, które nazywano „recydywą specjalną"32, jednakprzedstawianie ich szczegółowej charakterystyki wykracza poza ramy niniejszego opracowania (Jurij Bytko wskazał, że w ostatnich 11 rozdziałach ustawy prawodawca wprowadził więcej niż 220 takich typów czynów zabronionych) ${ }^{33}$. Na marginesie należy dodać, że w części ogólnej Kodeksu w stosunku do małoletnich ustanowiono szczególne warunki odpowiedzialności karnej za powtórne przestępstwo, o czym była mowa w art. 150 k.k.g.p.: „,małoletni,

(art. 156) [art. 156 k.k.g.p. w rosyjskim wydaniu ustawy - dop. J. M.] jest bardzo surowa (...) uderzająca niestosunkowość skarcenia w przypadkach art. 139 (art. 138 k.k.g.p. w rosyjskiej wersji ustawy - dop. J. M.] i 157 [art. 156 k.k.g.p. w rosyjskiej wersji ustawy - dop. J. M.]: w pierwszym bowiem przestępca ulega dodatkowemu powtórnemu skarceniu za pierwsze przestępstwo, w drugim za niektóre ze zbiegających się przestępstw właściwie żadnej kary nie poniesie" - zob. S. Budziński, O powtarzaniu przestęstw..., s. 8-9.

${ }_{32}$ Н.С. Таганцев, Русское уголовное право..., t. 2, s. 423; Э.Г. Шкредова, Множественность преступлений..., s. 10.

33 Ю.И. Бытко, Учение о рецидиве преступлений в российском уголовном праве: История и современность, Saratów 1988, s. 42. Jako przykłady typów czynów zabronionych charakteryzujących się powtarzalnością można wskazać:

- art. 1058 Za sprzedaż surowego albo niedopieczonego chleba winny podlega:

karze pieniężnej równej cenie sprzedaży tak całkowitej już sprzedanego przez niego, jak i znalezionego u niego dopuszczonego do sprzedaży chleba;

surowy albo niedopieczony chleb odbiera się na korzyść miejscowych zakładów dobroczynnych do dopieczenia albo zamienienia w suchary.

Dopuszczający się tego wykroczenia drugi raz podlegają:

takiejże karze pieniężnej podwojonej;

po raz trzeci,

oprócz kary pieniężnej podwojonej, aresztowi na czas od siedmiu dni do trzech tygodni.

- art. 2148: Za kradzież dokonaną w czasie pożaru, powodzi lub innej klęski winni podlegają:

za pierwszym razem - pozbawieniu wszystkich szczególnych, osobiście i według stanu otrzymanych przez nich praw i przywilejów i zesłaniu na mieszkanie do guberni Irkuckiej lub Jenisejskiej z uwięzieniem na okres od dwóch do trzech lat, z zakazem wjazdu do innych Syberyjskich guberni na okres określony przez sąd od ośmiu do dziesięciu lat, lub, jeśli nie są oni według prawa wyłączeni od kar cielesnych, chłoście w mierze określonej przez art. 35 niniejszego Kodeksu dla drugiego stopnia kary tego rodzaju i oddaniu do poprawczych aresztanckich rot na okres od sześciu do ośmiu lat;

za drugim razem - tym samym karom powiększonym o jeden stopień;

a za trzecim - pozbawieniu wszelkich praw i zesłaniu do Syberii na osiedlenie, i jeśli nie są oni według prawa wyłączeniu od kar cielesnych, karze biczów przez kata określonej przez art. 22 niniejszego Kodeksu dla drugiego stopnia tej kary. 
mający od dziesięciu do czternastu lat i niepełnoletni, którzy po postępowaniu sądowym i ukaraniu za przestępstwo, dopuszczą się powtórnie tego samego, albo równego lub cięższego przestępstwa, podlegają za to nowe przestępstwo jednakowo z pełnoletnimi karze określonej w ustawie, jednak z uwolnieniem od kar cielesnych albo ze zmniejszeniem ich miary według zasad wyżej postanowionych w art. 144 i 145 ".

\section{WYDANIE Z 1857 R.}

W odniesieniu do konstrukcji powtarzania przestępstw oraz wymiaru kar za powtarzanie przepisy Kodeksu nie uległy modyfikacji ani w 1857 r., ani w 1866 r., ani w 1885 r. Ponadto nadal nie zostały ustalone zasady orzekania kary w sytuacji, gdy sprawca popełnił przestępstwo po wydaniu wyroku w pierwszej sprawie za zbieg przestępstw, a przed odbyciem kary. W tym okresie nadal nie dochodziło do redukcji kar i kara za nowe przestępstwo była wykonywana oddzielnie po odbyciu poprzedniej kary łącznej.

\section{USTAWA O KARACH WYMIERZANYCH PRZEZ SĘDZIÓW POKOJU Z 1864 R.}

Na wstępie rozważań o kolejnej nowelizacji Kodeksu kar głównych i poprawczych warto zwrócić uwagę na reformę wymiaru sprawiedliwości przeprowadzoną przez cara Aleksandra II w 1864 r., która miała na celu wprowadzenie do systemu prawa zasad humanitaryzmu oraz prostszych zasad stosowania prawa przez sąd (m.in. wyrugowano możliwość kar cielesnych dla kobiet oraz ograniczono karę chłosty). W zakresie omawianej problematyki za ważne należy uznać unormowania ustawy o karach wymierzanych przez sędziów pokoju (dalej: ustawa), która dotyczyła wykroczeń, za które sędzia pokoju mógł orzec: naganę, upomnienie, przestrogę, karę pieniężną nie wyższą niż 300 rubli, areszt na okres do 3 miesięcy oraz osadzenie w wieży na okres nie dłuższy niż rok (art. 1 ustawy).

Regulacja powtarzania występków w ustawie o karach wymierzanych przez sędziów pokoju była postępowa. Zgodnie art. 14 pkt 3 ustawy ${ }^{34}$ powtarzanie występków stanowiło okoliczność zwiększającą winę i polegającą na powtórzeniu tego samego lub popełnieniu jednorodnego wykroczenia w ciągu roku od ,pociągnięcia do kary" (ros. после присуждения к наказанию). Z jednej strony powyższym uregulowaniem po raz pierwszy ustawodawca zdecydował się wprowadzić jednoznaczne przesłanki powtarzania, jeśli chodzi o kategorię wykroczeń, składa-

\footnotetext{
${ }^{34}$ Art. pkt 3: Za okoliczności zwiększające winę podsądnego głównie uważa się:

(...) powtórzenie tego samego lub popełnienie jednorodnego występku w okresie jednego roku po pociągnięciu do kary.
} 
jących się na powtórzenie (to samo wykroczenie lub wykroczenie jednorodne) ${ }^{35}$. Niemniej jednak za wadę należy uznać brak ogólnych zasad wymiaru kary, gdyż wymiar ten był określony oddzielnie dla każdego typu czynu zabronionego w części szczególnej, zatem w sposób bardzo kazuistyczny. Trzeba również zwrócić uwagę, że w art. 14 pkt 3 ustawy posłużono się innym terminem niż dotychczas podczas gdy w Kodeksie kar głównych i poprawczych dotąd używano terminu „po postępowaniu sądowym i ukaraniu za pierwsze" - to w ww. ustawie była mowa o ,pociągnięciu do kary”. Zakaz wykładni synonimicznej narzucał potrzebę niejednakowego rozumienia tych pojęć, w konsekwencji czego jako ,pociągnięcie do kary" traktowano uprawomocnienie się wyroku za pierwszy czyn bez konieczności odbycia orzeczonej kary w całości ${ }^{36}$. Warunek ten co prawda można potraktować jako pierwowzór dzisiejszego pojęcia skazania jako przesłanki recydywy, jednak na gruncie ówcześnie obowiązującego prawa wyznaczanie odmiennych przesłanek tych samych instytucji ujętych w różnych aktach prawnych z pewnością nie służyło ujednoliceniu i systematyzacji wielości przestępstw.

Nowość stanowiło ponadto wprowadzenie terminu (jeden rok), po upływie którego niemożliwe było zakwalifikowanie kolejnego wykroczenia jako powtórzonego, w związku z czym wówczas okoliczność ta nie stanowiła podstawy do podwyższenia stopnia winy i kary. Wprowadzenie tego warunku spotkało się z aprobatą przedstawicieli piśmiennictwa ${ }^{37}$, co również należy ocenić pozytywnie i wskazać, że w późniejszym okresie wymóg ten został wpisany w znamiona recydywy.

\section{KODEKS KAR GŁÓWNYCH I POPRAWCZYCH - WYDANIE 1892 R.}

W Kodeksie kar głównych i poprawczych w 1892 r..$^{38}$ doszło do szeregu modyfikacji, co było motywowane chęcią ujednolicenia zasad odpowiedzialności za powtórzenie, gdyż od chwili wejścia w życie ustawy o karach wymierzanych

${ }^{35}$ Po raz pierwszy także prawodawca użył terminu ,przestępstwo jednorodne” - zob. Э.Г. Шкредова, Множественность преступлений.., s. 28.

${ }^{36}$ Н.С. Таганцев, Систематический свод...

${ }^{37}$ S. Budziński, Начала уголовного права..., s. 281.

${ }^{38}$ Ewelina Szkriedowa trafnie zauważa, że istnieje spór co do tego, w którym roku doszło do zmian w tym zakresie. Jak już wyżej wspomniano, zostały opublikowane trzy główne wydania Kodeksu kar głównych i poprawczych: w 1857, 1866 i 1885 r., chociaż modyfikacji poszczególnych przepisów było znacznie więcej. W związku z powyższym można znaleźć sporne informacje odnośnie do tego, kiedy weszły w życie opisywane nowelizacje. Jurij Bytko wskazuje, że doszło do nich w 1892 r., powołując się na pracę Nikołaja Tagancewa wydaną w 1904 r. (Ю.И. Бытко, Учение о рецидиве..., s. 44). Sprzeczności w tym zakresie - jak uważa Ewelina Szkriedowa - wynikają z posługiwania się wydaniem Kodeksu z 1885 r. ze zmianami na 1904 r., kiedy to nowelizacja z 1892 r. już obowiązywała (w oparciu o wersję ustawy z 1904 r. czynione są również ustalenia co do treści ustawy w 1892 r. w niniejszej pracy) - zob. Э.Г. Шкредова, Множественность преступлений..., 
przez sędziów pokoju w 1864 r. istniały dwa odmienne systemy rozumienia pojęcia „powtórzenie” oraz dwa różne sposoby wymierzania za nie kary. W związku z powyższym zmieniła się kodeksowa definicja powtórzenia. Nowy art. 131 k.k.g.p. stanowił, że:

Art. 131. Za okoliczność zwiększającą winę i karę uważa się także powtórzenie przestępstwa lub wykroczenia, $\mathrm{tj}$. popełnienie tego samego lub jednorodnego czynu przestępnego po odbyciu kary za poprzedzający czyn przestępny lub po uwolnieniu od kary na podstawie ogólnego ułaskawiającego manifestu lub szczególnego Monarszego ułaskawienia.

W wypadkach wskazanych szczególnie przez prawo karę za powtórzenie podwyższa się nie tylko w mierze, ale i w stopniu lub rodzaju.

Dodatkowo w art. 132 k.k.g.p. ${ }^{39}$ wprowadzono, po pierwsze, zasadę, że skutkiem powtórzenia przestępstwa lub wykroczenia jest nie tylko wyższy wymiar kary, ale może być nią również orzeczenie kary surowszego stopnia lub rodzaju. Po drugie, po raz pierwszy w historii rosyjskiej kodyfikacji prawa karnego określono okresy w zależności od statusu sprawcy lub okresu, po upływie którego

s. 22; Jednakże fakt wydania przez Nikołaj Tagancewa komentarza do Kodeksu kar głównych i poprawczych z 1885 r. świadczy o tym, że omawiane zmiany weszły w życie w 1892 r., gdyż publikacja ta ich nie zawiera - zob. Н.С. Таганцев, Уложение о наказаниях..., s. 97-141. Chociaż warto w tym miejscu nadmienić, że w innej, wcześniejszej pracy Ewelina Szkriedowa stwierdziła, że to ustawą z 1892 r. doszło do zmian w omawianym zakresie - zob. Э.Г. Шкредова, Совокупность преступлений по уголовному законодателтству и доктрине воторой половине XIX в., „Государство и Право" 2008, nr 8, s. 66.

${ }^{39}$ Art. 132. Powtórzenie przestępstw i wykroczeń pociąga za sobą zwiększenie odpowiedzialności tylko w wypadkach, jeśli od czasu odbycia kary lub po ułaskawieniu nie minęło:

1) dla osób skazanych na pozbawienie wszystkich prawa stanu i na zesłanie na ciężkie roboty lub na zesłanie - dziesięć lat;

2) dla osób skazanych na pozbawienie wszystkich szczególnych, osobiście i według stanu otrzymanych praw i przywilejów i na oddanie do poprawczych aresztanckich rót - osiem lat;

3) dla osób skazanych na pozbawienie wszystkich szczególnych, osobiście i według stanu otrzymanych praw i przywilejów na osadzenie w wieży (areszt publiczny) lub na osadzenie w twierdzy z pozbawienie niektórych szczególnych praw i przywilejów albo bez pozbawienia tychże, lub na osadzenie w wieży z pozbawieniem niektórych szczególnych praw i przywilejów - pięć lat;

4) dla dworzan, osób duchownych, zakonników i obywateli honorowych skazanych w wypadkach wskazanych w w przypisie do punktu V art. 30 niniejszego Kodeksu na osadzenie w wieży z pozbawieniem wszystkich szczególnych, osobiście i według staniu otrzymanych przez nich praw i przywilejów, a także dla wszystkich osób skazanych za kradzież, oszustwo, przywłaszczenie lub sprzeniewierzenie cudzego majątku na osadzenie w wieży bez pozbawienia praw - trzy lata;

5) dla osób skazanych na osadzenie w wieży za inne niż wskazane w punkcie 4 niniejszego artykułu czyny przestępne, a także dla osób skazanych za zabór lub samowolny wyręb lasu i za czyny przestępne przewidziane przez art. 104.2 i 106.1 Statutu o karach wymierzanych przez sędziów pokoju - dwa lata;

6) dla osób skazanych na inne kary niż osadzenie w wieży - jeden rok. 
pociągnięcie do odpowiedzialności karnej za powtórzenie oraz - w konsekwencji - zaostrzenie tej odpowiedzialności, było niemożliwe.

Warto wspomnieć, że o wcześniej wspomnianej modyfikacji w definiowaniu powtórzenia przestępstw, do której doszło, można mówić tylko, jeśli do chwili nowelizacji z 1892 r. opowiedzieć się za poglądem, że od chwili wejścia w życie Kodeksu kar głównych i poprawczych powtórzenie przestępstw stanowiło popełnienie jakiegokolwiek przestępstwa ${ }^{40}$ albo popełnienie tego samego przestępstwa ${ }^{41}$, o czym była już mowa wcześniej. Jeśli natomiast stanąć na stanowisku, że wymogiem aktualizacji normy o powtórzeniu przestępstw jest to, by nowy czyn był albo tożsamy z poprzednim albo jednorodny z nim ${ }^{42}$, to wówczas oczywiście w 1892 r. w tej części do żadnych modyfikacji nie doszło.

W porównaniu do wcześniejszego stanu prawnego popełnienie nowego przestępstwa po upływie wskazanego w ustawie czasu od chwili odbycia kary lub ułaskawienia (art. 132 k.k.g.p.) nie stanowiło podstawy do obostrzenia odpowiedzialności karnej na podstawie art. 131 k.k.g.p., co należy ocenić pozytywnie, gdyż zmiana ta doprowadziła do tego, że w razie dokonania kolejnego czynu dawała prawo do odpowiadania na ogólnych, a nie zaostrzonych, zasadach po upływie określonego terminu.

Literalna wykładnia ww. przepisów daje asumpt do twierdzenia, że zastosowanie instytucji powtórzenia przestępstw było obowiązkowe, gdyż ustawodawca posłużył się takimi kategorycznymi sformułowaniami jak: „uważa się” (ros. признается - art. 131 zd. 1 k.k.g.p.), „podwyższa się” (ros. усиливается - art. 131 zd. 2 k.k.g.p.), ,pociąga za sobą” (ros. влечеть - art. 132 k.k.g.p.). Jednakże Nikołaj Tagancew, interpretując treść art. 131 zd. 2 k.k.g.p. (okoliczność, że tylko w wypadkach wskazanych przez ustawodawcę podwyższa się nie tylko miarę, ale również stopień lub rodzaj kary) stwierdził, że jeśli nie zachodzi taki wypadek, to sąd może fakultatywnie, a nie musi zaostrzyć wymiar kary za powtórzenie przestępstw ${ }^{43}$. Stanowisko to niestety nie zostało w żaden sposób uzasadnione. Można się w tym zakresie jedynie domyślać, że zapatrywanie to było skutkiem braku wskazania przez ustawodawcę generalnych zasad wymiaru kary za powtarzanie w części ogólnej Kodeksu, a takiego generalne zasady dotychczas były przewidziane.

Nie sposób jednak zgodzić się z takim poglądem, gdyż - jak już wyżej podkreślono - prawodawca użył określeń stanowczych. Sformułowanie „podwyższa się nie tylko w mierze, ale i w stopniu lub rodzaju", które pojawia się w art. 131 zd. 2

40 Г.С. Досаева, Множественность преступлений.., s. 38; Н.С. Таганцев, О повторении преступлений..., s. 286.

${ }^{41}$ S. Budziński, O powtarzaniu przestepstw..., s. 23-24.

${ }^{42}$ Н.С. Таганцев, Русское уголовное право..., t. 2, s. 424.

43 Ibidem, s. 425. 
k.k.g.p. można ponadto interpretować jako wskazanie, że zasadą było obowiązkowe podwyższenie wysokości kary, a tylko w niektórych przypadkach wskazanych przez prawo sąd musiał także orzec wyższy stopień lub rodzaj kary.

\section{ANALIZA PIŚMIENNICTWA XIX W.}

Badając sposób unormowania powtórzenia przestępstw, wyeksponować trzeba istotę umieszczenia $\mathrm{w}$ systemie prawnym tej instytucji. Jak podkreślano wcześniej, konieczność zaostrzenia kary w przypadku powtórnego popełnienia tego samego przestępstwa lub przestępstwa tego samego rodzaju uzasadniana była okolicznością, że skoro sprawca popełnił kolejne przestępstwo, to kara za poprzednie nie spełniła swoich celów ${ }^{44}$. Dodatkowo potrzeba bardziej surowego ukarania recydywistów ${ }^{45}$ była związana $\mathrm{z}$ rozwojem socjologicznej szkoły prawa karnego, której przedstawicielami na gruncie rosyjskim byli m.in.: Michaił Gierniet, Siergiej Gogiel, Paweł Liubinskij oraz Siergiej Poznyszew ${ }^{46}$. W świetle zapatrywań tej szkoły to skłonność i przyzwyczajenie do popełniania przestępstw oraz brak poważania prawa powinny spotkać się z dotkliwą reakcją karną ${ }^{47}$.

Jednakże ze względu na kategoryczność i surowość rozwiązań legislacyjnych w tym zakresie (np. obowiązek wymierzenia najwyższej miary za powtórzone przestępstwo - art. 138 k.k.g.p. w pierwotnej treści Kodeksu, a w większości przypadków kary za poszczególne powtórzone przestępstwa były oznaczone w części szczególnej ustawy) były one poddawane wzmożonej krytyce, m.in. podkreślano, że „podwojenie czynów przestępczych wcale nie oznacza podwojenia niebezpieczeństwa i zepsucia woli”"48, jak również, że nie można zawsze bezwarunkowo utrzymywać, że uprzednia kara była niewystarczająca i nie spełniła swojej roli, a w przypadku stwierdzenia, że w istocie kara ta była zbyt łagodna, społeczeństwo nie powinno obwiniać za to przestępcy, skoro samo nie znalazło odpowiednich środków go resocjalizujących ${ }^{49}$.

Bardziej stanowcze, a zarazem nowatorskie na gruncie tak polskiej, jak i rosyjskiej literatury jest stanowisko Stanisława Budzińskiego, który stwierdził, że

${ }_{44}$ А. Лохвицкий, Курс русского уголовного права, Sankt Petersburg 1871, s. 175-176; Н.С. Таганцев, Русское уголовное право..., t. 2, s. 419.

${ }^{45}$ Mimo że terminy „recydywa” i ,recydywista” nie były wyrażeniem ustawowym, to większość doktryny już w XIX w. posługiwała się nimi wymiennie, mówiąc o powtórzeniu przestępstw.

46 Э.Г. Шкредова, Множественность преступлений..., s. 18.

47 В.В. Есипов, Очерк русского уголовного права. Часть общая. Преступления и преступники. Наказание и наказуемье, Sankt Petersburg 1898, s. 170.

${ }^{48}$ Н.Д. Сергеевский, Русское уголовное право. Часть общая. Пособие к лекииям, Sankt Petersburg 1913, s. 364.

49 В.В. Есипов, Преступность и меры воздействия, Warszawa 1900, ss. 17-18. 
„zasada surowszego karania powtarzania jest zabytkiem srogości średniowiecznej, uparcie uszanowanym przez prawodawstwo. (...) Niezawsze dopuszczający się nowego przestępstwa dokonywa je z niepoprawności, złego nałogu lub lekceważenia prawa: może uczynić to z nędzy, w uniesieniu namiętności i t. d. Na zasadzie przypuszczenia nie można więzić przestępcy. Surowsze ukaranie w takim razie naruszy zasadę ne bis in idem, bo nadmiar nad zwykłą wielkość kary stanowić będzie powtórne ukaranie za czyn pierwszy. Najwłaściwiej pozostawić uznaniu sędziego, czy w danym razie powtórzenie oznacza niebezpiecznego przestępcę lub nie, i czy ten zasługuje na podwyższenie kary. Podwyższenie takie powinno następować tylko w zakresie, i nigdy maximum kary w danym przypadku nie przekraczać, jeśli nie chcemy dwa razy za jeden czyn karać" ${ }^{50}$. Autor ten upatrywał zatem naruszenia zasady karania dwa razy za to samo tylko wtedy, gdy ze względu na pewne okoliczności sprawy sprawca nie zasługiwał na zaostrzenie kary za powtórne przestępstwo. Natomiast co do samej idei podwyższania wymiaru kary w ramach powtórzenia przestępstw i ewentualnej sprzeczności z regułą ne bis in idem Stanisław Budziński się nie wypowiadał, postulował jedynie wprowadzenie fakultatywnego uprawnienia sędziego do zaostrzania kary.

Z kolei Nikołaj Tagancew, badając zagraniczną literaturę traktującą o powtarzaniu przestępstw, odnosił się negatywnie do poglądu, że konstrukcja ta narusza zakaz podwójnego karania, twierdząc, że w ramach powtórzenia sprawca nie jest sądzony i karany za poprzedni czyn, lecz są brane pod uwagę tylko te zmiany, które poprzedni czyn ,wniósł” w nowe przestępstwo. Autor ten stał na stanowisku, że wcześniejsza karalność zmienia stronę przedmiotową kolejnego czynu, w tym jego społeczną szkodliwość. Co więcej, potrzebę zaostrzenia kary uzasadniał również stroną podmiotową nowego zachowania ze względu na stopień niepoprawności czy nawyknięcia do popełniania przestępstw przez sprawcę ${ }^{51}$. Te okoliczności - zdaniem N.S. Tagancewa - dawały podstawę do zaostrzenia kary za powtórne przestępstwo ${ }^{52}$.

Jak się zatem okazuje, problematyka traktowania powtórzenia przestępstw jako okoliczności wpływającej na wyższy stopień winy i wymiar kary wcale nie była taka oczywista. Już na tym etapie rozwoju rosyjskiej nauki prawa karnego podawano w wątpliwość konieczność surowszego traktowania recydywistów.

${ }^{50}$ S. Budziński, Wykład porównawczy prawa karnego, Warszawa 1868, ss. 248-249; zob. także: idem, Начала уголовного права..., s. 279.

${ }^{51}$ Inni autorzy również wskazywali, że nie samo powtórzenie przestępstw, a nałóg sprawcy do popełniania przestępstw stanowi podstawę do wyższego wymiaru kary - zob. Л.С. Белогриц-Котляревский, Учебник русского уголовного права. Общая и особенная части, Kijów 1903, s. 322; С.В. Познышев, Учение о карательных мерах, Moskwa 1908, s. 166.

${ }_{52}$ Н.С. Таганцев, Русское уголовное право..., t. 2, s. 418. 
Przedstawiciele piśmiennictwa za warunek konstytutywny powtórzenia przestępstw co do zasady uważali konieczność odbycia całej kary. Warto w tym miejscu zwrócić uwagę, że abstrahując od uregulowań ustawowych, a przedstawiając jedynie swoje poglądy, Nikołaj Tagancew przewidywał możliwość zakwalifikowania kolejnego zachowania sprawczego jako powtórzenie, jeśli kara została odbyta chociażby w 2/3 jej wysokości ${ }^{53}$. Podobne stanowisko przedstawił Alieksandr Łochwickij oraz Siergiej Poznyszew, twierdząc, że warunkiem skazania sprawcy w ramach powtórzenia przestępstw było odbycie przynajmniej części kary ${ }^{54}$. Z drugiej strony można spotkać się ze zdaniem, że w ostateczności wystarczające było popełnienie nowego przestępstwa po wydaniu wyroku ${ }^{55}$. Ustawodawca jednak w XIX w. był konsekwentny i niezmiennie dla kwalifikacji zachowania jako powtórzonego wymagał, by sprawca odbył całość kary za poprzednie przestępstwo.

\section{PODSUMOWANIE}

Rozważając modyfikacje dotyczące powtórzenia przestępstw, do których doszło w omawianym okresie, zauważyć należy, że nie wypracowano elastycznych zasad wymiaru kary w tym zakresie. Rzecz jasna, sąd zachowywał największą swobodę w czasie obowiązywania Zwodu praw, gdyż wówczas nie były przewidziane żadne szczególne reguły co do orzekania kary za kolejny czyn przestępczy. Następnie był całkowicie związany wolą prawodawcy i począwszy od wejścia w życie Kodeksu kar głównych i poprawczych w pierwotnej wersji (1845 r.), sąd zawsze wymierzał najwyższą miarę kary za powtórzone przestępstwo (art. 138). Wówczas przewidziany był również szereg typów czynów zabronionych, których znamieniem kwalifikującym było popełnienie tego samego czynu po raz drugi, trzeci, itd. Taki sposób penalizacji powtarzających się przestępstw stanowi w istocie pierwowzór późniejszej i obowiązującej również w Kodeksie karnym Rosji z 1996 r. (art. 151¹, art. 180) niejednokrotności. W ramach ostatniej, głównej nowelizacji Kodeksu z 1892 r. doszło do radykalnych zmian, które były analogiczne do regulacji zamieszczonych w ustawie o karach wymierzanych przez sędziów pokoju z 1864 r. i które wprowadziły nową jakość do rosyjskiego prawodawstwo poprzez wymóg, by następny czyn był dokonany we wskazanym okresie.

53 Idem, О повторении преступлений..., s. 61.

54 А. Лохвицкий, Курс русского уголовного права.., s. 177; С.В. Познышев, Основные начала науки уголовного права. Общая часть уголовного права, Moskwa 1912, s. 630.

${ }_{55}^{5}$ Н.Д. Сергеевский, Русское уголовное право ..., s. 366. 


\title{
THE RECURRENCE OF CRIME (RECIDIVISM) IN RUSSIAN CRIMINAL LAW IN THE 19TH CENTURY
}

\begin{abstract}
The legal institution of the recurrence of crime is nothing new in Russian criminal law. Recidivism, in the colloquial meaning of the term, is considered to be a repetition of the offence. Furthermore, it is treated as such regardless of whether the new forbidden act is the same, similar or different from the previous one. It is also classified as recidivism regardless of the period of time which elapsed from the previous criminal act. The following article presents the construction of the recurrence of crime in the Russian legislation in the 19th century (at the time the legislator did not use the term "recidivism"). Furthermore, an analysis of various regulations from that period is included, i.e., the Digest of Laws of the Russian Empire, the Code of Criminal and Correctional Punishments as well as the statute concerning punishments imposed by the justices of the peace.
\end{abstract}

\section{RÉPÉTITION (RÉCIDIVE) DES INFRACTIONS \\ DANS LE DROIT PÉNAL RUSSE AU XIXÈME SIÈCLE}

\section{Résumé}

L'institution du retour à l'infraction n'est pas une nouveauté dans le droit pénal russe. Au sens commun, la récidive est considérée comme la commission d'une nouvelle infraction, peu importe quel type d'acte prohibé elle représente - le même, similaire ou différent, et indépendamment du délai suivant l'acte précédent. Dans cet article, nous présenterons l'institution de la répétition des infractions dans la législation russe du XIXème siècle (lorsque le législateur n'utilisait pas le terme «récidive») et nous analyserons les différents règlements de cette période, à savoir: le Recueil de jurisprudence, le Code des peines principales et correctionnelles et la loi sur les sanctions imposées par les juges de paix. 